\title{
THE PROTECTIVENESS OF DOGS AND CATS POST RABIES VACCINATION IN BANJARBARU, INDONESIA
}

\author{
Harwanto $^{1,3}$, Heru Susetya ${ }^{2}$, Khrisdiana Putri ${ }^{2}$, Elfa Zuraida ${ }^{3}$, Widodo Pujiatmoko ${ }^{4}$ \\ ${ }^{1}$ Master of Veterinary Science, Faculty of Veterinary Medicine, Universitas Gadjah Mada, ${ }^{2}$ Department of \\ Veterinary Public Health, Faculty of Veterinary Medicine, Universitas Gadjah Mada, ${ }^{3}$ Balai Veteriner Banjarbaru, \\ Ministry of Agriculture, Indonesia, ${ }^{4}$ Banjarbaru Department of Agriculture, Fisheries and Food Security \\ Corresponding author: Heru Susetya, e-mail: herususetya@ugm.ac.id. Joint authors: H: drh.harwanto@gmail.com ; \\ KP: khrisdiana@ugm.ac.id; EZ: elfazuraida@gmail.com ; WP: widodo.syamil@gmail.com
}

\begin{abstract}
A sudden increase of rabies cases in proprietary cats and dogs in Banjarbaru has been identified in recent years. We aim to identify the effectiveness of dog and cat rabies vaccinations in Banjarbaru and to determine the risk factors that influence it. Determination of sample size using the Epitools.ausvet calculation method obtained 153 dogs and cats post vaccination randomly. The ELISA method was used to determine the protective antibody titer of samples $(\geq 0.5 \mathrm{IU} / \mathrm{ml})$ against rabies. Other primary data used to determine risk factors that affect the level of protection against rabies in dogs and cats were obtained from interviews with respondents. The results of the ELISA test and interview data from respondents were analyzed using IBM SPSS Statistics 21. Linear regression analysis showed that the type of vaccine A $(O R=19.03)$, age $(O R=7.52)$ and frequency of vaccination $(O R=2.52)$ significantly affected protective antibody titers. Unweighted logistic regression analysis showed the factor associated together with the protectiveness is the frequency of vaccination $(\mathrm{OR}=2.52)$. The protectiveness $\operatorname{dog}$ and cat against rabies is very low based on the constant value in linear regression of $0.17 \mathrm{IU} / \mathrm{ml}$ and logistic regression of $2.5 \times 10^{-10} \%$. Risk factors that affect the protectiveness of dog and cats against rabies are age ( $>1$ years), type of vaccine (vaccine A) and frequency of vaccination (>1time). Repetition of vaccination is a priority action in increasing the effectiveness of vaccination.
\end{abstract}

Keyword: Banjarbaru, protectiveness, rabies, risk factors

\section{Introduction}

Rabies or known as mad dog disease, is one of the animal disease that can be transmitted to humans (zoonotic) [1]. Rabies is caused by the Rabies virus of the Lyssavirus genus, family Rhabdoviridae. Rabies virus is an RNA virus, included in the order Mononegavirales. Rabies virus has a shape like a bullet rod (cylindrical) with one cone-shaped end. Rabies virus measuring $75 \mathrm{~nm}$ in diameter and $180 \mathrm{~nm}$ in length, has a genome length of about 12 kilobase [2].

The immune system has two lines of defense: innate immunity and adaptive immunity. Innate immunity is the first immunological, non-specific (antigen independent) mechanism for fighting against an intruding pathogen. It is a rapid immune response, occurring within minutes or hours after aggression, that has no immunologic memory. Adaptive immunity, on the other hand, is antigen-dependent and antigen-specific; it has the capacity for memory, which enables the host to moint a more rapid and efficient immune response upon subsquent exposure to the antigen [3]. Another definition also states that herd immunity does not require 
immunization of all members of the group to eliminate a disease. Microbes cannot sustain themselves and disease will disappears at vaccination coverage rates of less than $100 \%$ [4].

According to a report from the Department of Agriculture and Fisheries Food Security (DKP3) Banjarbaru, rabies cases recurred in Banjarbaru in January 2013. The last rabies case occurred in 2006. Rabies case in 2013 occurred in a cat that bites the owner. Brain samples were taken to the Banjarbaru Veterinary Laboratory and the results showed positive Fluorescent Antibody Technique (FAT). Since then, rabies cases in Banjarbaru began to spread in other district and reached its peak in 2018, with a total sample tested from 2013 to 2018 were positive for FAT as many as 23 samples consisting of 13 positive cases of rabies in dogs ( 7 males and 6 females) and 10 positive cases of rabies in cats $(9$ male and 1 female). Based on the calculation of the estimated number of rabies-carrying animal (HPR) in Banjarbaru in 2019, there are 78,318 heads of HPR. Most of them are cats with an estimated number of 76,679 heads $(97.91 \%)$, then dogs 1,275 heads (1.63\%) and other animals 364 heads $(0.47 \%)$. Rabies-carrying animal bites (GHPR) also showed an increase from 2013 to December 2018, with a total number is 353 HPR bites [5]. Fast respond and appropriate treatment is always done in case of human bites. Good coordination between the Food, Agriculture and Fisheries Office of Banjarbaru with the local public health center and the Banjarbaru Veterinary Center in handling bite cases is the key to successful handling of HPR bites so that they do not cause human casualties. Based on the increasing numbers of positive cases and HPR bites in Banjarbaru, we aim to identify the effectiveness of $\operatorname{dog}$ and cat rabies vaccinations and to determine the risk factors that influence it

\section{Methods}

The ethical requirements of the study were approved by the Faculty of Veterinary Medicine Research Ethics Commission, Universitas Gajah Mada, Yogyakarta, Number: 0084/EC-FKH/Int/2019. Inform consent was obtained from all respondents.

Based on a report from the Food Security, Agriculture and Fisheries Office of Banjarbaru, the number of rabies cases in 2018 was 14 positive for FAT out of 27 suspected rabies cases. The Ausvet epitool is used to calculate the true prevalence estimate by entering the sensitivity and specificity values of the FAT test with a 95\% confidence level obtained a True Prevalence (Blaker CL) of 0.5231. The same method applies to estimating animal and herd-level prevalence, with herd sensitivity and herd-specificity replaced by Animal-level values for estimating true livestock prevalence. [6]and obtained 150 samples.

A total of 153 samples were taken from dogs and cats which had been vaccinated randomly Banjarbaru. We have taken 1-2 $\mathrm{ml}$ of blood, drawn through femoral vein or saphenous vein using a $3 \mathrm{ml}$ sterile syringe. The syringe that has been filled with blood is then left at room temperature until serum and the clot of blood cells separated. The serum is then transferred into a sterile microtube. The microtube containing the serum then stored in a coolbox / box with a cold temperature (filled with ice cubes), or directly put in a freezer at $20^{\circ} \mathrm{C}$ until the serum is being tested. Before being used for testing, the serum is first inactivated by placing the tube containing the serum in a water heater (waterbath) with a temperature of $56^{\circ} \mathrm{C}$ for 30 minutes.

The antibody titer against rabies was considered the dependent variable $(\mathrm{Y})$, while the independent variable (X) was the host factor (age, animal, sex), and raising management (origin of animal, education of the owner, brand of vaccine). The enzyme-linked immunosorbent assay (ELISA) method was used to determine the antibody titer against rabies with a rabies ELISA kit from the Center for Veterinaria Farma (PUSVETMA). The test was carried out with the indirect-ELISA technique. Serum titer are determined based on optical density (OD) in the form of units (EU) equivalent to OIE standard serum. The result of a protective titer is indicated by a value of $\geq 0.6 \mathrm{EU} / \mathrm{ml}$, which is equivalent to $\geq 0.5 \mathrm{IU} / \mathrm{ml}$ as a protective standard for antibody titers. The data obtained were analyzed using IBM SPSS Statistics 21.

Chi-square test was used to analyze the significance of association between rabies incidence and the risk factors [7]. The calculation of odds-ratio (OR) is used 
to analyze the strength or closeness of the relationship of disease (dependent variable) to various independent variables (independent variable) at $95 \%$ confidence interval [8]. Logistic regression analysis was used to determine the effect of the independent variables simultaneously on the incidence of rabies and to obtain a logit model for the incidence of rabies. Model accuracy was analyzed using the Hosmer-Lemeshow Goodness of Fit test [9].

\section{Results}

Table 1. Descriptive results.

\begin{tabular}{ll}
\hline No & \multicolumn{1}{c}{ Variable } \\
\hline 1 & Study \\
& (1) Primary School \\
& (2) Junior HS \\
& (3) Senior HS \\
& (4) College \\
2 & Animal
\end{tabular}

3
(1) Cat
(2) Dog

Results

$$
\begin{array}{r}
7,8 \%(12 / 153) \\
13,1 \%(20 / 153) \\
36,6 \%(56 / 153) \\
42,5 \%(65 / 153)
\end{array}
$$

$78,4 \%(120 / 153)$

$21,6 \%(33 / 153)$

Sex
(1) Female
$42,5 \%(65 / 153)$
(2) Male
$57,5 \%(88 / 153)$

$4 \quad$ Age
(1) < 12 month
(2) $\geq 12$ month
$25,5 \%(39 / 153)$
$74,5 \%(114 / 153)$

5 Origin of animal
(1) Ownbreed
(2) Purchased
(3) Gift
(4) Finding

$58,8 \%(90 / 153)$

6 Frequencyof

Vaccination

(1) $<2$ time

(2) $\geq 2$ time

7 Vaccine brand

(1) Vaccine A

(2) Vaccine B

$86,3 \%(132 / 153)$

$13,7 \%(21 / 153)$

8 Antibody titer

(1) Non protective $77,1 \%(118 / 153)$

(2) Protective 22,9\% (35/153)

9 District
(1) South Banjarbaru
$47,1 \%(72 / 153)$
(2) North Banjarbaru
$52,9 \%(81 / 153)$

From these data, it shows that the sampling carried out is in accordance with the proportion of the dogs and cats population taken. The sex of the male animal was $57.5 \%(88 / 153)$ and the female was $42.5 \%$ (65/153), this is almost balanced in terms of sampling. For the dogs and cats age taken, it shows that more than 1 years old is $74.5 \%(114 / 153)$ and less than 1 year old is $25.5 \%$ (39/153). This is in accordance with the target sample, namely the dogs and cats postvaccination, where the average age of the dogs and cats vaccinated is more than 1 year. Most of the dogs and cats raised came from own breed $58.8 \%$ (90/153), gift $22.2 \% \quad(34 / 153)$ and purchased $13.1 \%(20 / 153)$, while the remaining was $5.9 \%(9 / 153)$ is the dogs and cats from findings. This data shows that there are still stray dogs and cats in Banjarbaru, which is indicated by finding. The frequency of vaccination once was $51.6 \%(79 / 153)$ and equal or more than twice as high as $48.4 \%(74 / 153)$, this shows that there are still not many repeat vaccinations or boosters done. The ability of dogs or cats to survive natural infections does not always depend on antibody titers, but dogs and cats able to form protective antibodies after vaccination are more likely to survive against natural infections [10].

In bivariate terms, the protectiveness was associated with the host (age and origin of the cat), management (frequency of vaccination and vaccine brand) (Table 2.). This is consistent with research that the frequency of repeated vaccinations $(\mathrm{OR}=2.52) 2.52$ times higher than no repetition. Age more than 1 year has an effect on immunity that is 7.5 times higher (OR $=7.54$ ), because at the age of more than 1 year has been revaccinated so that the higher antibody titer is formed. This could be one of the reasons why the protectiveness is still low because there are no repeat vaccinations because the vaccination booster is one of the factors that can increase the antibody titer in vaccinated animals [11]. The ownership factor from the purchase may also have an effect on the level of immunity ( $\mathrm{P}<0.05)$, but it is not risky because the OR is only 0.18 . The type of vaccine used was the $A$ vaccine at $77.1 \%$ and the $\mathrm{B}$ vaccine at $13.7 \%$. Vaccine A had more effect on immunity $(\mathrm{P}<0.05)$ and was 19.03 times more immune than vaccine $\mathrm{B}(\mathrm{OR}=$ 19.03). Adjuvants are ingredients in the manufacture of vaccines that function to maximize the body's immune system response to antigens). Vaccine $A$ uses aluminum phosphate adjuvant [12] which can increase the protection and long duration of immunity compared to B vaccine which uses aluminum hydroxine gel adjuvant [13]. 
Table 2. Chi square $\left(X^{2}\right)$ and Odd Ratio (OR)

\begin{tabular}{|c|c|c|c|c|c|}
\hline $\begin{array}{l}\mathrm{N} \\
\mathrm{o}\end{array}$ & Variables & $\begin{array}{l}\text { Chi Squi } \\
\left(X^{2}\right)\end{array}$ & P-Value & OR & $95 \% \mathrm{CI}$ \\
\hline 1 & $\begin{array}{l}\text { Study } \\
\text { (1) Basic } \\
\text { School } \\
\text { (2) Junior HS } \\
\text { (3) Senior HS } \\
\text { (4) College }\end{array}$ & $0,103^{\text {ns }}$ & 0,748 & 0,862 & $0,348-2,135$ \\
\hline 2 & $\begin{array}{l}\text { Animal } \\
\text { (1) Cat } \\
\text { (2) Dog }\end{array}$ & $0,45^{\mathrm{ns}}$ & 0,833 & 1,102 & $0,446-2,722$ \\
\hline 3 & $\begin{array}{l}\text { Sex } \\
\text { (1) Female } \\
\text { (2) Male }\end{array}$ & $0,115^{\mathrm{ns}}$ & 0,735 & 1,142 & $0,530-2,461$ \\
\hline 4 & $\begin{array}{l}\text { Age } \\
\text { (1) }<12 \text { month } \\
\text { (2) } \geq 12 \text { month }\end{array}$ & 9,345 & $0,002 *$ & 7,537 & $\begin{array}{l}1,717- \\
33,087\end{array}$ \\
\hline 5 & $\begin{array}{l}\text { Origin of animal } \\
\text { (1) Ownbreed }\end{array}$ & $0,053^{\text {ns }}$ & 0,818 & 1,094 & $0,510-2,347$ \\
\hline & (2) Purchased & 13,458 & $0,000 *$ & 0,180 & $0,067-0,483$ \\
\hline & (3) Gift & $3,059^{\text {ns }}$ & 0,080 & 2,642 & $0,861-8,103$ \\
\hline & (4) Finding & $2,836^{\mathrm{ns}}$ & 0,092 & 1,321 & $1,204-1,449$ \\
\hline 6 & $\begin{array}{l}\text { Freq of Vacc } \\
\text { (1) }<2 \text { time } \\
\text { (2) } \geq 2 \text { time }\end{array}$ & 5,469 & $0,019^{*}$ & 2,518 & $1,146-5,533$ \\
\hline 7 & $\begin{array}{l}\text { Vaccine brand } \\
\text { (1) Vaccine A } \\
\text { (2) Vaccine B }\end{array}$ & 39,216 & $0,000^{*}$ & 19,032 & $\begin{array}{l}6,237- \\
58,073\end{array}$ \\
\hline 8 & $\begin{array}{l}\text { Antibody titer } \\
\text { (1) Non } \\
\text { protective }\end{array}$ & $0,322 \mathrm{~ns}$ & 0,571 & 0,803 & $0,375-1,717$ \\
\hline & (2) Protectuve & $0,322 \mathrm{~ns}$ & 0,571 & 1,246 & $0,582-2,666$ \\
\hline
\end{tabular}

$* \mathrm{P}<0,05 ;{ }^{\mathrm{ns}}$ nir signifikan

Tabel 3. Analisis regresi linier titer antibodi HPR (anjing dan kucing) terhadap rabies.

\begin{tabular}{|c|c|c|c|c|c|c|}
\hline & & Coe & cients $^{\mathrm{a}}$ & & & \\
\hline & del & Unstan & Irdized & Standardiz & $\mathrm{t}$ & Sig. \\
\hline & & Coeff & ients & Coefficien & & \\
\hline & & B & $\begin{array}{l}\text { Std. } \\
\text { Error }\end{array}$ & Beta & & \\
\hline & (Constant) & .925 & .384 & & 2.409 & .017 \\
\hline & Study & .059 & .058 & .067 & 1.023 & .308 \\
\hline & Animal & -.092 & .065 & -.105 & -1.412 & .160 \\
\hline & Sex & .055 & .046 & .075 & 1.192 & .235 \\
\hline & Age & .148 & .061 & .179 & 2.428 & .016 \\
\hline & Ownbreed & -.179 & .118 & -.246 & -1.516 & .132 \\
\hline 1 & Pirchased & -.484 & .134 & -.442 & -3.623 & .000 \\
\hline & Gift & -.129 & .126 & -.149 & -1.027 & .306 \\
\hline & Finding & -.021 & .152 & -.013 & -.137 & .892 \\
\hline & Freq.of Vacc & .116 & .051 & .161 & 2.275 & .024 \\
\hline & Vaccine brand & .568 & .071 & .542 & 7.978 & .000 \\
\hline & South Banjarbaru & -.181 & .128 & -.251 & -1.417 & .159 \\
\hline & North Banjarbaru & -.225 & .131 & -.311 & -1.718 & .088 \\
\hline
\end{tabular}

a. Dependent Variable: Protective

Multivariate testing (linear and logistic regression) was used to determine the model of the protectiveness of dogs and cats in Banjarbaru and is useful for evaluating rabies control programs in Banjarbaru (Tables 3 and 4). The linear regression analysis obtained equations: $\mathrm{Y}=$ $-1.744+0.885\left(\mathrm{X}_{1}\right.$, vaccine brand $)+0.314\left(\mathrm{X}_{2}\right.$, frequency of vaccination). The logistic regression equation can be written as follows:

$$
\begin{aligned}
\mathrm{p} & =\mathrm{e}(\mathrm{Y}=1 / \mathrm{X} 1) \\
& =1 / 1+\mathrm{e}^{-(-1.744)} \\
& =1 / 1+(2.718)^{(1.744)} \\
& =0.17
\end{aligned}
$$

$\mathrm{e}=2.718$ (natural number)

The constant value in linear regression means that the probability of dog and cats has a protective titer of only $0.17 \mathrm{IU} / \mathrm{ml}$. In the linear regression model, the constant value means that the antibody titer is only $0.17 \mathrm{IU} / \mathrm{ml}$ if the influence of other variables is ignored.

The logistic regression analysis obtained equations: $\operatorname{Pr}($ protect $=1 / \mathrm{x})=-22.189+3.054\left(\mathrm{x}_{1}\right.$, frequency of vaccination). The logistic regression equation can be written as follows:

$$
\begin{aligned}
\mathrm{p} & =\mathrm{e}(\mathrm{Y}=1 / \mathrm{X} 1) \\
& =1 / 1+\mathrm{e}^{-(-22.189)} \\
& =1 / 1+(2.718)^{(22.189)} \\
& =2.5 \times 10^{-10}
\end{aligned}
$$

$\mathrm{e}=2.718$ (natural number)

Tabel 4. The logistic regression

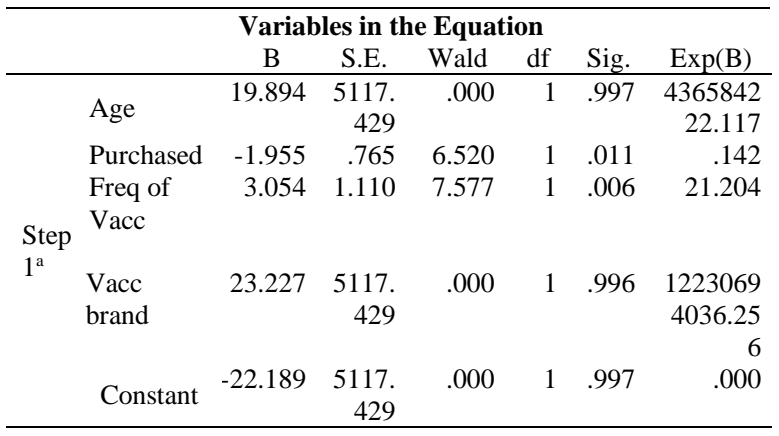

a. Variable(s) entered on step 1: age, purchase, vaccine frequency, vaccine brand.

\section{Discussion}

The constant value in logistic regression means that the probability of dog and cats has a protective titer of only $2.5 \times 10^{-10} \%$. In the logisic regression model, the constant value means that the antibody titer is only $2.5 \times 10^{-10} \%$ if the influence of other variables is ignored.

Therefore, both models conclude a low level of protectiveness and susceptibility to rabies. These results support the fact that the prevalence of protective antibody titers is low in Banjarbaru. One variable with the same effect that appears in the logistic and linear regression

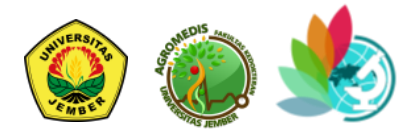


is the frequency of vaccination. Based on the output above, it can be shown that from several independent variables included in the model, it can be seen that the significant variables, namely those with a probability value of less than 0.05 , are the variables of origin of dogs and cats (purchased), vaccine brand, age and vaccination frequency, while the logistic regression shows that there is 1 significant independent variable, namely the frequency of the vaccination.

The vaccine frequency variable was significant at 0.05 . From the logistic regression equation, it can be seen that the log odds of the effectiveness of the mean are positively influenced by the frequency of vaccination. The Odds Ratio value at this level of protection can be shown in the Exp (B) value as in the output above, namely for the frequency of vaccinations carried out by 21 times, it will increase the level of rabies protectivity in dogs and cats by $20.4 \%$.

\section{Conclusions}

The protectiveness of dogs and cats against rabies in banjarbaru is very low. Risk factors that affect the protectiveness of dog and cats against rabies are age ( $>1$ years), type of vaccine (vaccine A) and frequency of vaccination (>1time). Repetition of vaccination and use vaccine A brand is a priority action in increasing the effectiveness of vaccination rabies in Banjarbaru.

\section{Acknowledgment}

The authors would like to send their gratitude to Disease Investigation Centre Banjarbaru and the Department of Food, Fisheries, and Agriculture of Banjarbaru.

\section{References}

[1] World Health Organization., 2020. Available from: https://www.who.int/healthtopics/rabies\#tab=tab_1 Rabies. Retrieved on 14-04-2020.

[2] CDC, 2019 "What is Rabies?". from: https://www.cdc.gov/rabies/index.html\#: :text= Rabies\%20is\%20a\%20fatal\%20but,raccoons\%2 C\%20skunks\%2C\%20and\%20foxes. Retrieved on 14-04-2020.
[3] J. S. Marshall, R. Warrington, W. Watson, and H. L. Kim. 2018 "An introduction to immunology and immunopathology," Allergy, Asthma Clin. Immunol., vol. 14, no. Suppl 1, pp. 1-8.

[4] E. R. Isaacs, david, MD. Moxon, 1996 "A practical approach to pediatric infectoius/ Davis Isaacs and E. Richard Moxon", 3rd ed. Oxford: New York: Churchill Livingstone.

[5] Anonymus, 2020, "Laporan Rabies DKP3 Kota Banjarbaru Tahun 2019".

[6] G. J. G. Roger W Humphry, Angus Cameron,2004 "A practical approach to calculate sample size for herd prevalence surveys," Prev Vet Med, vol. 65, no. 3-4, pp. 173-178.

[7] Notoatmodjo, S, 2012 "Prof.-Dr.-SoekidjoNotoatmodjo-Metodologi-PenelitianKesehatan.-intro.pdf".Ed. Rev.-xix, 243. PT. RINEKA CIPTA. Jakarta.

[8] S. W. Martin, A. H. Meek, and P. Willeberg, 1987, "Sampling methods_Vet_Epidem_Chapter_2,".

[9] M. D. Begg, 2009, "An introduction to categorical data analysis" (2nd edn). Alan Agresti, John Wiley \& Sons, Inc., Hoboken, New Jersey, 2007, vol. 28, no. 11.

[10] M. F. Aubert, 1992 "Practical significance of rabies antibodies in cats and dogs.," Rev. Sci. Tech., vol. 11, no. 3, pp. 735-760.

[11] Frymus T, Addie D, Belák S, et al. Feline Rabies: ABCD Guidelines on Prevention and Management. Journal of Feline Medicine and Surgery. 2009;11(7):585-593.

[12] MDS, "Nobivac Rabies," 2020, from: https://www.msd-animal-

health.co.in/products/nobivac-rabies/.

Retrieved on 14-04-2020.

[13] Pusvetma, 2019 "Vaksinasi adalah kunci, sebuah lompatan tehnologi vaksin rabies produksi dalam negeri". from: http://pusvetma.ditjenpkh.pertanian.go.id/m ain.php?page $=$ detail_berita\&id $=172$.. Retrieved on 14-04-2020. 
